\title{
Development E-Insurance Based on the Provisions of the Insurance Policy for the Certainty of Evidentiary Civil Procedural Law in Indonesia
}

\author{
Lukman IIman Nurhakim ${ }^{1}$, Erni Rohaini ${ }^{2}$, Toto Tohir Suriatmadja ${ }^{3}$ \\ 1,2,3 Universitas Islam Bandung, Indonesia \\ Email: ernirohaini29@gmail.com
}

\begin{abstract}
The development of $\mathrm{E}$ - Insurance in its match was a development of the Electronic Insurance Policy Agreement or Jo. E-Polis. The insurance agreement or written policy as stipulated by OJK Regulation on Insurance Products and Insurance Product Marketing as an rationing of the Code of Commercial as a special norm of the understanding of Insurance Policy. Unlike the Electronic Insurance Policy Agreement or E-Polis was accommodated by OJK Regulation on Insurance in 2015, E-Insurance developed as a result of insurance needs for electronic or e-commerce trading transactions that do not yet had special arrangements. This was because in E-Insurance, the business' person did not make hardcopy either the Insurance Policy Agreement or the policy agreement to be further conveyed to the customer or the insured. Furthermore, the Evidentiary Power E-Insurance in the Civil Procedural Law could not be equated: as a means of proof of letter because the parties in the proof cannot show the original (hardcopy). At least judges under Article 10 of the Court of Justice Power Act could categorize E-Insurance as a means of proof of guessing, because the parties in the evidence could not show the original (hardcopy). Thus, a law-level rule was required a law that can accommodate E-Insurance related to proof of civil justice
\end{abstract}

Keywords: Evidentiary Law, E-Insurance, Insurance Policy Agreement.

\section{A. INTRODUCTION}

The idea of financial loss in times of uncertainty has become a presupposition at which a person's expectation, is on the other end of the spectrum to the ongoing course of actions. Usually, people come up with a lot of solutions when faced with such dilemmas, to avoid, to prevent, to divert, or to accept the matters at hand wholeheartedly. The means of insurance within our civil code expected to fulfill the public demands at managing risks by splitting them up to bits or averting the potentials to all parties.

An important characteristic of the Continental legal system is the requirement for law to be compiled in a comprehensive piece of legislation before becoming legally binding. This particular check to the sovereign's arbitrary nature preserves legal certainty, however, the rapid development in technology might hinder the need to innovate within society (het ink achten feiten aan). Therefore, as constituted in this country's legal system, statutes are the primary source of law should the need for a legal remedy arises. 
Laws concerning insurance regulate the state of affairs partially, regulated by both Law Number 40 Year 2014 on Indonesia Insurance Law and Commercial Code of Indonesia (KUHD). Thus, Insurance can be best described as a contract to define a consensus by both parties in ensuring the principles of coverage. Aside from the aforementioned Acts, Law Number 11y ear 2008, has offered a new perspective ever since the respective act was put into force. Any legal action can be conducted through electronic mediums (Computer, electronic network, and other electronic devices), following it being declared legally valid in the eyes of the court.

Insurance policy is the basis of bound for both parties, between the insured and the insuring, as regulated in Article 255 of Commercial Code of Indonesia, stating policy is an affirmative statement that a mutual consent has been reached, despite the fact the contract has yet to be issued. In other words, an insurance policy is a contract to facilitate the existing agreement, yet this may contradict the regulations as constituted in Article 258, paragraph (1), Commercial Code of Indonesia, which reserves the right for an insurance policy to be presented as evidence in court.

Currently, regulations concerning E-insurance are still under the general category, as the similarity with others' services that is to cover the loss of goods under abrupt occurrences. This could bring a halt to the growth of E-commerce that fully acknowledges the potential for the damage on goods under unexpected circumstances, whether by an error on the medium or any loss caused by any transaction. Consequently, various issues often lead to dispute among Insurance company and their clients. These are a number of causes of a general insurance claim dispute archived by Indonesia's Mediation \& Arbitration Agency (2016) (hence, shall be known as BMAI):

1. The sale of insurance products

2. Reasons to purchase insurance coverage

3. Misinterpretation of the insurance policy

4. Miscalculation on the coverage of loss of goods by the Insuring party.

5. Loss Adjuster the insured's mis judgement on the role of loss adjuster

6. Handling of a claim

The development of E-commerce is not only accompanied by benefits but also several shortcomings, hence legal accommodation in the scope of private law on electronic transaction is a necessity, along with ITE Law. The conduct of transactions within private sector evolve overtime, so does electronic medium that has been a part of international commerce. It is at the utmost importance for the usage of technology to have legal certainty, especially in relation to E-commerce.

E-insurance is a form of agreement, liable for a great number of commerce throughout the web. Putting the ease of use for many web users into consideration, it will certainly result in efficiency for an action on the internet to also be constituted by an electronic regulation, strictly speaking in shape alone. In $2019,21 \%$ of total population (57,3 million people) have been utilizing e-commerce (https://www.sirclo.com). Owing to this fact, not only the law must accommodate but also to be in line with E-commerce regulations. Meanwhile, only a handful of 
Indonesia's population are taking advantage of E-insurance. Low awareness of this particular facility is also a contributing factor to this phenomenon in general. In other words, E-insurance is still limited to the extent of policy agreement in electronic manners. Suffice to say, the development of E-insurance is not accommodated by law, only to be found within ministerial regulations or Financial Services Authority Regulation number 23/POJK.05/2015 Year 2015 on Insurance Products and the Promotion of Insurance Products, hereafter shall be known as POJK Insurance.

Legal protection in E- commerce transactions is a matter with the utmost urgency for all types of loss in any way as a result of trade, and should be in a close watch by the legislature to put forth a bill that accommodates electronic insurance products. This aims to ensure safety over transactions made on the web, hence diverting disadvantageous prospects in line with principle of Risk Management.

Policy agreement is regulated in Article 19 paragraph (1) Government Regulation Number 73 Year 1992 on Insurance Business Conduct, stating the wording of insurance agreement must not, in any way, include sentences, phrases, or words to avoid potential vagueness that may give rise to different interpretations on matters of risk of termination of Insurance account, liability of insurance company and its clients, or hindering the insured of their right to a claim. The particular article sets the requirements for each clause to be mutually understood by both parties before the signing of agreement, in conjunction to Article 258 paragraph (1) of Indonesia's Commercial Code, from this point forward shall be used as evidence.

Eventually, insurance policy agreement is devised not only in conventional form on a piece of paper, but also gradually keep up with the advent of technology with the development of policy agreement in electronic form. The regulations of POJK Insurance is a set of rules applied only to products and services in financial sector without any capacity to dictate a definition of policy agreement as Commercial code has given. Clearly, there has yet to be a piece of legislation within its capability to regulate legal standing of E- insurance policy, to the extent of being a legal ground for dispute settlement. By the closed court nature in civil proceedings, admissible evidence is limited to the set of rules regulated under the Civil Procedural Code. Therefore, e- insurance has no clear sets of measure once the stage is moving towards evidentiary hearings.

\section{B. METHOD}

This is a purely normative legal research. The norm under study is the norm concerning e-insurance. The object of research is the legal norm provided for under Law Number 40 Year 2014 on Indonesia Insurance Law and Commercial Code of Indonesia (KUHD). For an understanding of said norm, literature research has been undertaken with the objective of obtaining primary and secondary legal materials through legal doctrines and document study of court decisions. Research has been conducted through qualitative data processing and deductive reasoning method of legal doctriness providing insight into the interpretation of development e-insurance 
based on the provisions of the insurance policy for the certainty of evidentiary civil procedural law in Indonesia.

\section{RESULT AND DISCUSSION}

\section{Existence of E-Insurance within Indonesia's Insurance Law}

Some scholars have come up with an approximation that insurance products had begun to take part in public life at the start of Nederlandsh Indissch Leven Verzekering En Liefrente Maatschappij (NILMIY) during Dutch colonial period. Forward into 1853, the first insurance company was established under the name of Bataviasche Zee End Brand Asurantie Maatschappij. In 1912, the first life insurance in Indonesia, Boemi Putra, was founded.

As part of global industry, the growth of this service is not only influenced by circumstances in host country or the surrounding regions, but also by many pieces of legislation in effect. This is indicated by fluctuating growth over the years, which reflects the condition of the economy in Indonesia. Data released by the Financial Services Authority (OJK) for the first semester of 2019, shows the total of insurance premiums peaked at IDR 221.14 trillion, 3\% higher compared to previous year period that is IDR 81,56 trillion for life insurance and IDR 40,13 trillion for general insurance. General Insurance in particular, did experience a significant growth, up to $20 \%$ in comparison to the previous year period (Sayekti, 2020).

IT tech facilitates a great deal of individuals to wrap up their work with ease, by one click of the mouse. E-Insurance is an elite and unique system allowing for policy holder to purchase and reserve the insurance policy in a dematerialized form, to a degree. It is an insurance analogue from savings account. Following the creation of E-insurance account, all insurance policies, life and general, might be deposited into one repository insurance (Pahuja \& Chitkara, 2016).

Along with the ever-increasing needs for E-Insurance, the majority of public has begun to come up with the notion of using protection in E-commerce transaction by diverting the cost of risk. Aside from all the loss might happen upon an individual's property, there will be a dispensation in form of coverage. Insurance provides a sense of assurance over the uncertain nature of E-commerce. Following the payment of Einsurance premium, the psychological burden of huge loss over a transaction in the future might be lifted up off consumers' state of mind. It will be a tremendous task to figure an analysis of the loss might come upon an individual, therefore insurance premium is a means to keeping the incurring losses at the lowest rate possible (Darwani, 2004).

E-commerce is a practice of transaction through electronic medium. A great number of world population spend the majority of their time on the internet to conduct trade activities in this manner to anyone at any given time. In other words, any transaction made over the internet is carried out without physical meeting taking place. Good faith and trust serve as the bases for this sort of transaction, hence the transaction occurs in a non-conventional way with physical invoice is practically nonexistent (Utomo, 2010). 
Customers may find a lot of advantages in various ways such as, browsing catalogues at a quicker pace, being updated for a new commodity in stock, etc. Online retails are usually competitive when it comes to product pricing. The ease of accessibility and lower price deduced from consumers, have given rise to a more detailed catalogue with a higher quality in that regard.

On the other hand, a number of technical and non-technical issues still linger around this practice. Lack of trust by the public of this relatively new system, either considered to be taboo or general disbelief that the goods will never arrive. By taking these perspectives in mind, it is at utmost importance of the public to manage these risks with E- Insurance. For every transaction made after the insurance premium is paid, all unforeseen risks will be under coverage of E-insurance. Although, many consumers do not pay attention to the fine print on the insurance policy.

E-commerce provides a wide range of benefits for a more accessible service to goods sold on the internet. A consumer is always informed with the latest update of products. This also puts many sellers in a more competitive environment to set the standard of service at all-time high.

The utilization of the internet and information technology to produce and distribute insurance services is the backbone of E-insurance. Insurance premiums, distribution of insurance policies, and processing of claims payments can be completed on the web, in some countries regulatory (surveillance) and technological (technical) restrictions may not allow for this action to be carried out. However, many people over the globe pay to insurance premium and online distribution of policies while the regulations are constantly being modified to suit current needs. The impact from E-Insurance on efficiency includes:

1. Reducing the cost of administrative process through business automation

2. Lowering expenditures spent on commission of third-party distributors offering the service (Meshkat et al., 2010).

As a form of electronic transactions, the practice of E-insurance is regulated under article 1 number 2 of ITE Law, stated as follows: "Electronic transaction is a liability committed through various mediums of electronic devices or network". Insurance is a form of agreement under the general rule of Book III of Civil Procedural Code along with Chapter 255 Code of Commerce that also set out "Insurance service must be conducted on a written deed, hence shall be known as policy". Nevertheless, Man S Sastrawidjaja remarked on the A quo article should it be in conjunction to chapter 257 and 258 Code of Commerce then we may find to the conclusion of both parties have given consent without no written deed in advanced. Therefore, an insurance policy serves only as an evidence contrary to the common perception that it is an essential requirement.

Law Number 2 Year 1992 on Systems of Insurance Undertakings had been amended in 2014. The basis for this amendment is the significant importance of anticipating rapid growth within the global economy and in response to simultaneous expansion of E-commerce along with ITE Law. 
Article 4 of ITE Law interprets the aim on information technology and electronic transaction to give rise to law \& order and justice for web users and its provider. It is also stated in Chapter 5, any information in electronic form is accepted as a lawful evidence in court. Despite all of this, synchronization at the grand scale has not been carried out among many pieces of legislation and Code of Commerce.

POJK insurance opens up the possibility of a insurance policy to remain in electronic data as stated in Chapter 21 POJK Insurance: "Insurance policy is issued in either written form or digital data." However, should it be published to the insured, POJK Insurance remains steadfast on the obligation that the deed to be read out in person and remains in written form once consent from the insured is given. In contradiction with the previous Article 255 Code of Commerce, there seems to be no adequate regulation in sight as of now.

Chapter 40 paragraph (1) of Systems of Insurance Undertakings Law sets the rule that the government must participate in facilitating the use of information technology and transactions in relation to the legislations in force. Harmonious relation among government regulations and legislative acts, is required to maintain order in the scope of E-insurance conduct, hence a steady system alongside social norms, will bring about the rule of law in respect to Radbruch's observation (Tanya, 2010).

Article 257, paragraph 1, Code of commerce, stipulates the insurance agreement come into being as soon as it is held, the mutual rights and obligations of the insured and the insurer from then on, even before the signing of policy. Article 257 states that the insurance agreement is consensual. Nonetheless, Article 255 requires a policy as evidence explicitly explains the legal bond between the Insurer and the Insured.

The crisscrossing definition of E-insurance and E-policy are not interchangeable in the frame of one electronic document category. Thus, only administrative sanctions are appertained by POJK Insurance. In managing the situation, OJK issued a regulation in 2014 as a means to accommodate policy holder, the insured, and participants under protection of the financial authority.

Essentially, validity in terms of insurance policy agreement, referring to Article 1320 of the Civil Code, come into being once all parties bind themselves liable to each once consent is given. Article 257 of the Commercial Code could override the provisions of the Insurance Policy Agreement. However, should a dispute arise then it may bring more conundrums into the already problematic circumstances. In assessing strength of evidence, judges are bound by the arrangement of evidence by law. The "consent" given, stated within the Civil Code, should not be due to impetuousness of the signatory in regard to the subject of agreement. In addition, all parties involved must be in sound state of mind to be a signatory. This is a common situation for many to sign without being aware of the small details in an insurance policy.

Currently, the legislation sets the rule of insurance contract meanwhile Law Number 2 Year 1992 brings about the regulations in scope of its activity. Clauses 
within policy must align with the rather outdated dutch colonial Code of Commerce that no longer fits with the way of modern financial situation. The following sets an example for the argument: "The insurance deed or other documents equivalent in nature to it, as well as other integral parts of an insurance agreement, made in writing and contains the agreement between the insurance company and the policy holder". By definition stated above, the phrase "other documents" indicates POJK Insurance has granted sense of legality in the standing of E-policy as stated under article 21 POJK Insurance: "Insurance policy is issued in written or electronic form".

At the time of being issued in digital / electronic form, the company must obtain approval of the policy holder, the insured, or the participants. Furthermore, POJK Insurance requires obligations from the Insurance Company to be submitted in electronic form.

The concept of E-insurance sets out liability in accordance to Article 57 paragraph (1) POJK Insurance as follows: “The Financial Service Authority (OJK) shall dispatch a cease and desist letter to halt the promotion of an insurance product in such instances:

1. The marketed insurance packages are inconsistent to the final products which have obtained a letter of approval or registration letter referring to article 28 paragraph (1); and / or

2. Coverage included in Insurance policies is no longer compatible with the current legislation"

By definition, sanction could be charged to companies marketing E-policy products, such as: written warning, fine, or obligation for members of executive committee to take part in mandatory assessment, and revocation of business permit, expressed in article 60 paragraph (2) POJK Insurance.

Various aspects surrounding the regulations of E-insurance make it distinct in comparison to electronic policy. As a supplementary (accesoir) of a transaction on the web, it has certainly given rise of the means for many to utilize the fullest extent of computer application running over algorithm. The insured, web users in this instance, is only required to give consent to the charge of premium on a direct link with the insuring party. Meanwhile, electronic policy simplifies the initial act of marketing conduct to potential clients by methods of telemarketing or promotion in e-mail comprising of either general or life insurance. In contrast to E-insurance packages cover mostly in the scope of transactions on the web.

Having a pivotal role in economic development on national scale, risk management in insurance sector should be held in high regard. Nonetheless, it might have yet to appear as such, in practice. According to National financial literacy poll held by OJK shows only 19,4 \% literate at such matters with the following 2,77\% are aware of current GDP and the rate of people in coverage of general insurance is only $0,41 \%$. This shows the low awareness of the public to be under coverage of general insurance (Windarto, 2020).

Within 2 year span since 2018, Tokopedia as one of the biggest marketplace in Indonesia recorded a rapid growth of E-insurance transactions by 20 fold in the last 
fiscal year (Catriana, 2020). The demand for transformation in business befits 4.0 industry is inevitable. In other words, there is a fine line between E-insurance and ITE Law on the matter of commerce over the web to be carefully managed, running the digital phenomenon under risk-management principle for the good of many.

\section{Evidence Strength of a E-Policy Deed within Evidentiary Proceedings in The Civil Procedural Code}

The advent of technology in information has given way to many methods of communication to others. Numerous forms of electronic media open up the wide possibility of narrowing the gap for many people across time and space by an abstract yet universal virtual environment.

The use of electronic evidence in commerce in particular is increasingly accepted in the community. However there has been no specific regulation in regard to electronic evidence. Nevertheless, new regulations have partially regulated and placed electronic evidence to be lawfully used in court, in Article 15 paragraph (1) and Article 12 paragraph (2) of Law Number 8 Year 1997 on Corporate Documents, stating: "Company documents containing microfilm or other media as referred to in Article 12 paragraph (1) and/or printouts are valid evidence". This explicitly states, electronic documents, company documents in particular, are legal evidence long before the issuance of the ITE Law.

An electronic document can only be valid if the electronic system being used is regulated within Law on Electronic Information and Transactions (ITE Law) specifically in article 6, which expresses "Electronic information and/or electronic documents are only valid on condition that any contained within the said document can be accessed, presented, preserved as whole, and liable to describe a specific condition.

On substance regarding electronic evidence is included in various legislations including but not limited to, Law on Corporate Document, and ITE Law. However, the procedures on this matter has yet to be regulated, especially on the strength of evidence that will be handed over to the judges to decide.

In accordance to article 6 ITE Law, the requirements for an electronic evidence to be deemed as lawful are:

1. Content of electronic evidence must be presentable for the judges to observe

2. Preservation of the original content, it must not undergo any modification up to the time of the hearing to safeguard its integrity; and

3. Electronic evidence must be obtained through procedures of transparent in its records to be held accountable in the eyes of the law.

In the current state of evidentiary law, the legal procedures in force have yet to accommodate electronic documents to be accepted in court, contrary to its common usage in the community. Judges are bound by law to take lawful evidence into account therefore should only decide their ruling strictly based on evidence as dictated by the statutes. Then it raises the question, of how the judges should discover a precedence (rechtvinding) at evidentiary of electronic information given the civil procedural code 
expresses that the lawfulness of evidence is through the acknowledgement by law (the Civil Procedural Code).

Electronic Transaction Act, a piece of legislation passed by the Parliament, of Singapore, features many resemblances with the ITE Law, yet the country has declared electronic documents as Secondary evidence, stated in Article 65. Meanwhile, the Netherlands assigns her judges to interpret the strength of evidence in evidentiary hearings on trials. This is in accordance with the Dutch Civil Code stating the equivalence of a signature on electronic devices to the physical ones (van Rhee).

As an insurance product covering over transactions conducted over the web, companies frequently provide the instructions to make claims for coverage on their website. Leaving out the details contained within the contracts has become a common occurrence, then worsened by the insufficient accommodations in Insurance Law to provide substance for a legal action, should the insured be inclined to. Consequently, a number of impediments may occur during the making of grounds for claim.

Comparable in certain respects, this issue is quite similar to with the requirement for Burden of proof, stated in Article $163 \mathrm{HIR}$, also in Article 1865 in the Civil Procedural Code goes as follows, "whoever claims the rights, refers to such rights or whoever objects to another's, shall prove the existence of the claim", thus the judge may adjure both parties in a civil trial to bear the burden of proof.

The exchange of consent in transactions is a part of the law of obligations. The shift to electronic medium has caused confusion to many in the community. An example of predicament s emerge as the result of cyber technology is the incredulity by the public to perceive sales receipt delivered on electronic devices as valid.

Evidentiary Law in Indonesia might have not accommodated the use of electronic documents as evidence, even though a number of efforts have been carried out on the course to its acknowledgement on civil trials. Achmad Ali \& Wiwie Heryani (2013) argue the 7 pieces of evidence as stated by the Civil Procedural Code: Written evidence or letter, statements, suspicions, confessions, oaths, expert statements, and site investigations are expressed plainly not to limit any new addition to the list, except to simply acknowledge its existence.

Contrary to the view, Sudikno Mertokusumo (2013) once remarked the absence of prohibition does not automatically conclude a particular matter is permitted or stricly forbidden to do. The scholar also argues the desired aim of evidentiary hearing is to grant judges with certitude over the truth.

According to HIR (Herzien Inlandsch Reglement), during evidentiary hearings Judges are bound to build upon their decision on lawful evidence as dictated by the statutes. Overtime, aside from the judicial power to examine, to pass judgement, and to decide a case, judges are also entitled to discover laws in order to bring a civil case into its conclusion. However, it should be noted that the conduct of this practice must not be in violation of the well-established convention.

Legal discovery is only used in practice, by judges presiding in a civil case. This method is directed at a case that is specific, concrete and individual in nature. Limited 
by regulations, in carrying out legal discovery a judge is under constraint of Article 21 $\mathrm{AB}$ (Algemene Bepalingen van Wetgeving) that states,in principle a judge may not make a landmark decision which will later be used as a universally established rule.

The absence of procedural rules regarding electronic insurance, albeit causes complications, cannot be a ground for judges to decline in participating to bring a resolute decision over a case. In accordance with Article 10 of the Judiciary Act setting out judges are in no capacity to reject a case that holds no clear ground onto it.

Moving to article 5 paragraph (1) of the Judiciary Act, it states that Judges are entrusted to observe the customs and value within a community whilst the statutes do not explicitly dictate so. It within the capacity of Judges to reviewing the evidence as contained in HIR/RBg. Such means to do so are by obtaining an expert's statements over specific matter, E-insurance in this case. Apart from that, suspicions may also be used to draw a conclusive decision.

Expert's statements could bring more insights for judges on a trial. For example, should the panel remain unclear of the truth over a civil case on finance, they may call on an expert to inform the panel of his/her expertise on electronic documents utilized in financial field. Thus, the testimony of an expert witnesses can bring more knowledge to the judge which can be used as a basis for evaluating the e-insurance policy.

The same can be said with suspicions, through this presupposition serving as a ground for judges to either accept E-insurance as evidence or straightly reject it. In other words, electronic evidence as the ITE Law wills it has served its purpose effectively. Yet, it still in dire need for coherent regulations to adjust with what POJK Insurance instructs.

If litigation involving electronic evidence in its current condition is not suitable for the disputing parties, then a more recommended means to resolve the issue is to go through on-litigation bodies, albeit with the dualism issue surrounding them. Article 45 paragraph (2) Law number 8 Year 1999 with Minister of Industry and Trade's decision Number 350 Year 2001 on the Implementation of Duties and Authorities of Consumer Dispute Resolution Bodies are the cause of it. In line with Article 1 Number 11 of Law on Consumer Protection sets out, Consumer Dispute Settlement Bodies are bodies assigned to resolve the disputes between business owners and consumers.

In addition, Article 54 of the Insurance Law also accommodates the protection of policyholders, the insured, or participants. Then, the implementation of Article 54 of the Insurance Law is further laid out in the Financial Services Authority Regulation Number 1/POJK.07/2014 on Alternative Institutions for Dispute Resolution in the Financial Sector as dictated by Article 6, also. Article 9 letter c of Law Number 21 of 2011 on the Financial Services Authority explicitly states that: "A party may exercise its right for a legal action concerning consumer dispute resolution in court or through other means outside the court based on the voluntary choice of the disputing parties",

We could come to the conclusion based on the commentary of the aforemention statutes, an electronic E-insurance dispute resolution could be achieved through 
litigation or alternative dispute resolution means as instructed by the Financial Service Authority along side in coordination with Indonesia's Mediation \& Arbitration Agency and/or Consumer Dispute Resolution Bodies. While the latter is available to go to in almost every city/regency in this country the decisions reached through them are usually overruled by the higher tier court under the ground not in its capacity to settle a breach of contract, meanwhile Indonesia's Mediation \& Arbitration Agency resides only in Jakarta, the capital of Indonesia.

Radbruch argued, it is a prequisite to be obedient to the law and values within the community, so the ideal presupposed condition might be achieved as certainty of the law is one of the means to do so (Tanya, 2010). In regard to E-Insurance dispute resolution, article 1267 of the Civil Procedural Code instructs : "The party to which a conjecture is not fulfilled, could choose; to compel others to fulfil the requirements of contract; to put forth a claim in court; or to pay indemnities on loss or interest." This allows for the possibility of undergoing Small Claims Court mechanism, when taking Supreme Court Regulation No. 4 of 2019 Amending the Supreme Court Regulation No. 2 of 2015 on Simple Lawsuit Resolution Procedures into account.

Yahya Harahap asserted that definition of simple, fast, and inexpensive judicial proceedings as an examination process goes through a relatively momentary period of time in accordance with the simplicity of procedural rules. Therefore, judges should prolong the proceedings meant to be simple and short under any unlawful ground (Iksandar \& Agustina, 2019).

Dispute resolutions in industrial and financial sectors are required to not generate new complications along the way. Various methods can be carried out to resolve disputes, either through litigation or alternative methods (Suparman, 2012). Meanwhile, business disputes are preferable to be resolved through non-litigation methods while this method oftentimes does not resolve the issue to its root. Once an agreement has been reached, the agreement can sometimes be not legally binding, thus it cannot compel other parties to implement it. Therefore, the non-litigation method is not suitable as the primary option (Fakhriah, 2013).

Litigation through the Small Claims Court mechanism can be carried out on legal action in a civil case within the value of a maximum of Rp. 500,000,000.00 (five hundred million rupiah), settled by proofing method. The scope excluded in dispute resolution through the Small Claims Court is regulated in Article 3 paragraph (2) of Supreme Court Regulation Number 4 Year 2019, reads:

Excluded from Small Claims Court are:

1. Any case whose mechanism is regulated through a special tribunal as the legislation dictates; or

2. Dispute over land ownership.

Furthermore, the due date for dispute resolution through the Small Claims Court is to be settled no later than 25 (twenty five) days from the day of the first session, instructed in Regulated under Article 5 paragraph (3) Supreme Court Regulation Number 2 of 2015. Lastly, Article 6A of Supreme Court Regulation Number 4 of 2019, reads: "Plaintiffs and Defendants could turn administration of the case to their favour, 
within court by using electronic devices, in accordance with the provisions of statutory regulations, along with Supreme Court Regulation Number 1 Year 2019.

With the Small Claims Court mechanism and E-litigation (electronic litigation), it is expected for changes of utility of electronic information to be put to use on many civil cases. This is in line with Supreme Court Regulation Number 1 Year 2019, reads:

1. Electronic evidence sent forth in the hearings by a party is lawful unless considered to be the opposite by suspicions from its receiver or recipient;

2. Should a conjecture be used as a ground, judges may order the respective party to present the evidence, hence displays it personally in front of the judges by using electronic devices to examine, whether the transmission of electronic data did truly happen or not;

3. During investigation, judges are obligated to ensure the existence of the recipient's account or the sender's, referring to the ownership of the account as the refuting party suggests.

\section{CONCLUSION}

The development of e-insurance is heavily determined by the growing needs for an insurance of a transaction made on the web without any coherent regulation over them. This is largely as result of companies' practice to not proved a printed copy of whether insurance policy, receipt, or insurance policy. Then, the strength of evidence of them are not in equivalent to a written letter in the Civil Procedural Code, for the reason that it cannot be physically presented in front of the judges.

This phenomenon will continue to rise up over time along-side the development of E-commerce. Company providing this service will likely to put on the best package deal with insurance included in almost every activity on the web. Further discussion on the subject is required to give a deeper comprehension in correlation to E-commerce transactions. Hopefully, the amendment on the Insurance Law and the enactment of the bill on Civil Procedure Code accommodating the regulation on electronic evidence might bring shelter to E-Insurance sector that will be a strategic issue along with the expansion of international trade.

\section{REFERENCES}

1. Ali, A., \& Heryani, W. (2013), Principles of Civil Evidentiary Law. Jakarta: Kencana.

2. Badan Mediasi dan Arbitrase Asuransi Indonesia. (2016). 10 Years of Forward Work and Governance. Jakarta: LP3i.

3. Darmawi, H. (2004). Insurance Management. Jakarta: Bumi Aksara.

4. Elsa Catriana, E. (2020). Looking at The Development of E-Commerce Insurance Products Transactions.

Retrieved from:

https://money.kompas.com/read/2020/10/13/122715126/menengokperkembangan-transaksi-produk-asuransi-di-e-commerce?page=all

5. Fakhriah, E. L. (2013). Small Claims Court Mechanism in Realizing Simple, Fast, and Light Cost Justice. Mimbar Hukum Volume, 25(2). 
6. Iksandar, M., \& Agustina, A. (2019). Application of Simple, Fast and Light Cost Judicial Principles in The Simulation of Divorce and Joint Property. Jurnal Hukum Keluarga dann Hukum Islam, 3(1).

7. Mertokusumo, S. (2013). Indonesian Civil Event Law revised edition. Yogyakarta: Cahaya Atma Pustaka.

8. Meshkat, L., Farkhondehnia, F., Bagheri, Z., Alihoseini, O., Sanayeimatak, S., Esmaeili, M., ... \& Masaratbakhsh, M. (2012). Electronic insurance and its application in e-commerce. Interdisciplinary Journal of contemporary research in business, 4(8), 640-647.

9. Pahuja, A., \& Saloni Chitkara, S. (2016). Perceptual exploration of Factors and Issues Affecting Adopting of E-Insurance. Case Stuies in Business and Management, $3(1)$.

10. Sayekti, I. M. S. (2019). Digital Insurance Era in Indonesia. Retrieved from: https://analisis.kontan.co.id/news/era-asuransi-digital-di-indonesia

11. Sirclo.com. (2020). Menilik Tren Perkembangan E-Commerce Indonesia di 2020. Retrieved from: https://www.sirclo.com/menilik-tren-perkembangan-ecommerce-indonesia-di-2020/

12. Suparman, E. (2012). Dispute Resolution in Business Law, Business Law Compilation Book. Bandung: Keni.

13. Tanya, B. L. (2010) Law Theory of Human Order Strategy Across Space and Generation, Yogyakarta: Genta Publishing.

14. Utomo, D. T. B. (2010). Dispute Resolution of Internet Trading Transactions (ECommerce). Hukum dan Dinamika Masyarakat, 7(2).

15. van Rhee, C. H. Evidence in Civil Law - Netherlands. Retrieved from: https://pf.um.si/site/assets/files/3223/evidence in civil law - netherlands.pdf>

16. Windarto. (2020). Insurance protects financial plans. Retrieved from: https://investor.id/investory/asuransi-melindungi-rencana-keuangan 